\title{
EFFECT OF INITIAL SUBSTRATE PH ON VERMICOMPOSTING USING PERIONYX EXCAVATUS (PERRIER, 1872)
}

\author{
N.B. SINGH - A.K. KHARE ${ }^{2}$ - D.S. BHARGAVA ${ }^{3}-$ S. BHATTACHARYA ${ }^{4, *}$ \\ *e-mail: environment_iet@rediffmail.com \\ ${ }^{1}$ Civil Engineering Department (Environmental Engineering), \\ Institute of Engineering and Technology, Sitapur Road, Lucknow, (U.P.) India, PIN-226021 \\ ${ }^{2}$ Institute of Engineering and Technology, Sitapur Road, Lucknow, (U. P.) India, PIN-226021 \\ ${ }^{3}$ Roorkee University, Bhargava Lane, Devpura, Haridwar (Uttranchal), India, PIN-249401 \\ ${ }^{4}$ Department of Electronics and Communication, \\ Institute of Engineering and Technology, Sitapur Road, Lucknow, (U. P.) India, PIN-226021 \\ *Corresponding author,
}

(Received $21^{\text {th }}$ July 2004 ; accepted $4^{\text {th }}$ August 2005)

\begin{abstract}
In view of the growing awareness about vermicomposting technology in recycling different types of organic wastes, this study was conducted to investigate the effect of initial substrate $\mathrm{pH}$ on vermicomposting. The substrate $\mathrm{pH}$ and ash content were evaluated as a function of time. The data showed an exponential relationship between substrate $\mathrm{pH}$ and time of vermicomposting while a phase Bode plot of a single zero system relationship between the ash content and time of vermicomposting. The model parameters of these relationships also had very good correlation with the initial substrate $\mathrm{pH}$. On the basis of obtained correlation between model parameters and initial substrate $\mathrm{pH}$, generalized predictive models for the substrate $\mathrm{pH}$ and ash content have been evolved in terms of the duration of vermicomposting and the initial substrate $\mathrm{pH}$. Plots of the predictive and experimentally observed values indicated a high robustness of predictive models. The study also revealed that the earthworm species Perionyx excavatus performs well in a wide range of substrate $\mathrm{pH}$. Near neutral initial substrate $\mathrm{pH}$ was found to be optimal for stabilization of waste with minimal processing time. The substrates having strong acidic initial $\mathrm{pH}$ were found to be less suitable for vermicomposting.
\end{abstract}

Keywords. earthworm, ash content, ph, vermicomposting, modeling

\section{Introduction}

The concept of vermicomposting started from the knowledge that certain species of earthworms consume a wide range of organic residues very rapidly, converting them into vermicompost, a humus-like, soil building substance in short time. The effective use of the earthworms in organic waste management requires a detailed understanding of the effect of the physico-chemical properties of the substrate. However, in spite of various studies on vermicomposting technology, the effect of the initial substrate $\mathrm{pH}$ on vermicomposting, being an important parameter has not received due attention of the investigators.

In view of this gap in knowledge, this study was particularly carried out to evaluate the variation effect of substrate $\mathrm{pH}$ on vermicomposting process using epigeic (surface burrowing) earthworm Perionyx excavatus (Perrier, 1872) (Megascolecidae).

\section{Review of literature}

Different varieties of earthworms have been recommended to be used in vermicomposting by various workers such as deep burrowing [7], shallow burrowing 
$[20,39]$, and surface dwellers $[1,6,9,12,20,21,35,39]$ and it has been established that the epigeic forms (surface dwellers) of earthworms are the most suitable for vermicomposting. The potential utilization of Perionyx excavatus, a shallow burrowing tropical Asian species [14, 38] distributed from the Himalayan Mountains to the plains of South India [20], in organic waste management has been reported by various authors $[13,17,18,20,21,26,29,30]$.

Earthworms are very sensitive to $\mathrm{pH}$, thus $\mathrm{pH}$ of soil or waste is sometimes a factor that limits the distribution, numbers and species of earthworms. Little information is available on effect of substrate $\mathrm{pH}$ during vermicomposting. Several researchers have stated that most species of earthworms prefer a $\mathrm{pH}$ of about 7.0 [2, 4, 28, 34]. However, Lumbricus terrestris occurs in soils with $\mathrm{pH} 5.4$ in Ohio, U.S.A. [27]. Satchell [36] reported that Bimastos eiseni, Dendrobaena octaedra and Dendrobaena rubida were acid tolerant species, and Allolobophora caliginosa, Allolobophora nocturna, Allolobophora longa were acid intolerant. He also reported that Lumbricus terrestris was not very sensitive to $\mathrm{pH}$, and Guild [15] agreed with this conclusion, although Richardson [31] disagreed. Bhawalkar [7] has suggested for neutral substrate $\mathrm{pH}$ to be used in vermicomposting. Edwards [11] has, however, reported a wide range of 5.0 to 9.0 for maximizing the productivity of earthworms in the waste management.

\section{Materials and methods}

The experiments were performed in truncated porous earthen pots of approximately 8 -liter capacity. The pots were initially filled to a $2.5 \mathrm{~cm}$ height with $12.5 \mathrm{~mm}$ nominal size chips of stone (aggregates), which was then covered with $2.5 \mathrm{~cm}$ thick layer of 1-5 $\mathrm{mm}$ size gravel to ensure proper drainage of excess water. A layer of local soil mixed with cow dung humus in 1:1 ratio of $2.5 \mathrm{~cm}$ thickness was used above the gravel bed to provide natural habitat to the earthworms. The experimental pots were kept in the laboratory without any attempt to control the ambient conditions.

Mixed vegetable residues (organic waste) collected from hostel kitchen were homogeneously mixed with citrus waste (lime and sweet lime) and dry mango powder in different proportions to alter the initial $\mathrm{pH}$ was used as substrate. The initially obtained substrate $\mathrm{pH}$ was $4.3,4.8,5.2,5.9,6.5$, and 6.9. These substrates were then top fed $\left(10 \mathrm{~cm}\right.$ thicknesses, average waste volume $\left.3.24 \times 10^{-3} \mathrm{~m}^{3}\right)$ into different experimental pots to investigate the effect of the initial substrate $\mathrm{pH}$ variation. Each variation was incubated with 40 local adult (clitellate) epigeic earthworms for the purpose of vermicomposting. Although the earthworm population tended to increase gradually, they were not counted later. Respective controls were maintained without earthworms.

The experimental pots were maintained at moisture content of $80 \%$ to ensure the optimum functioning of earthworms. The amount and interval of water sprinkling required to maintain the desired moisture content were obtained by several trials before starting the actual experimentation. The experiment was carried out till 45 days. The substrate samples were drawn on 3 days interval up to 30 days and thereafter 5 days interval from all the experimental pots. All the experiments were performed in replicates. About $5 \mathrm{~g}$ of samples were drawn from each pot. The samples were ground into paste to ensure the homogeneity of the substrate. The $\mathrm{pH}$ of substrate pastes were measured using $\mathrm{pH}$ paper inserting it into paste for a few seconds. Standard color chart was used for matching with the developed color. Moisture analysis was carried out by drying the samples in a hot air oven at $105^{\circ} \mathrm{C}$ for 24 hours. Ash content was determined by heating 
the moisture-free samples in a muffle furnace at $550{ }^{\circ} \mathrm{C}$ for 4 hours. The sample mean of measured $\mathrm{pH}$ and percent ash content computed on dry basis were used for analysis.

\section{Results}

The observed data for the variation of substrate $\mathrm{pH}(\phi)$ and ash content $(\alpha, \%$ dry basis) with different initial substrate $\mathrm{pH}(4.3,4.8,5.2,5.9,6.5$, and 6.9) including control (i.e. without earthworms) are presented in Tables 1 and 2 respectively.

Table 1. Variation of substrate $p H$ with different initial substrate $p H$ during vermicomposting

\begin{tabular}{|c|c|c|c|c|c|c|c|c|c|c|c|c|}
\hline \multirow{3}{*}{ days } & \multicolumn{12}{|c|}{ initial pH } \\
\hline & 4.3 & 4.8 & 5.2 & 5.9 & 6.5 & 6.9 & 4.3 & 4.8 & 5.2 & 5.9 & 6.5 & 6.9 \\
\hline & \multicolumn{6}{|c|}{ substrate $p H$ with earthworms } & \multicolumn{6}{|c|}{ substrate pH without earthworms } \\
\hline 0 & 4.3 & 4.8 & 5.2 & 5.9 & 6.5 & 6.9 & 4.3 & 4.8 & 5.2 & 5.9 & 6.5 & 6.9 \\
\hline 3 & 5.5 & 6.2 & 6.5 & 6.6 & 7.0 & 8.0 & 5.5 & 6.2 & 6.5 & 6.7 & 6.9 & 7.9 \\
\hline 6 & 6.7 & 7.2 & 7.2 & 7.3 & 8.1 & 8.2 & 6.8 & 7.3 & 7.4 & 7.5 & 8.0 & 8.3 \\
\hline 9 & 7.4 & 7.5 & 7.6 & 8.1 & 8.2 & 8.2 & 7.5 & 7.7 & 7.8 & 8.0 & 8.1 & 8.2 \\
\hline 12 & 8.0 & 8.1 & 8.1 & 8.2 & 8.2 & 8.1 & 8.1 & 8.2 & 8.2 & 8.2 & 8.2 & 8.2 \\
\hline 15 & 7.9 & 8.2 & 8.2 & 8.0 & 8.0 & 7.7 & 8.1 & 8.3 & 8.3 & 8.2 & 8.1 & 7.9 \\
\hline 18 & 7.6 & 8.1 & 8.0 & 7.7 & 7.5 & 7.5 & 8.0 & 8.1 & 8.2 & 8.1 & 8.0 & 7.8 \\
\hline 21 & 7.3 & 7.7 & 7.8 & 7.5 & 7.3 & 7.2 & 7.8 & 8.0 & 8.0 & 7.9 & 7.8 & 7.6 \\
\hline 24 & 7.2 & 7.3 & 7.4 & 7.3 & 7.2 & 7.1 & 7.5 & 7.7 & 7.8 & 7.8 & 7.5 & 7.4 \\
\hline 27 & 7.1 & 7.1 & 7.2 & 7.1 & 7.1 & 7.0 & 7.4 & 7.4 & 7.6 & 7.5 & 7.2 & 7.2 \\
\hline 30 & 7.0 & 7.0 & 7.0 & 7.0 & 7.0 & 7.0 & 7.2 & 7.2 & 7.2 & 7.1 & 7.0 & 6.9 \\
\hline 35 & 7.0 & 7.0 & 7.0 & 7.0 & 7.0 & 7.0 & 6.9 & 6.9 & 6.9 & 6.9 & 6.8 & 6.8 \\
\hline 40 & 7.0 & 7.0 & 7.0 & 7.0 & 7.0 & 7.0 & 6.9 & 6.9 & 6.9 & 6.9 & 6.8 & 6.8 \\
\hline 45 & 7.0 & 7.0 & 7.0 & 7.0 & 7.0 & 7.0 & 6.9 & 6.9 & 6.9 & 6.9 & 6.8 & 6.8 \\
\hline
\end{tabular}

The substrate $\mathrm{pH}$ increased progressively with almost similar trends till $6,9,12$, and 15 days in the experimental setups having respective initial substrate $\mathrm{pH}$ values of 6.9, $6.5,5.9$, and $(5.2,4.8,4.3)$. Maximum substrate $\mathrm{pH}$ was observed to be 8.2 in the experiments with initial $\mathrm{pH} 4.8$ and 5.2 while it was 8.3 in their respective controls. The substrate $\mathrm{pH}$ attained a declining trend thereafter and was observed to be neutral after 30 days of vermicomposting. The respective controls, however, showed little acidic $\mathrm{pH}$ (6.8 and 6.9) even after 30 days of aerobic composting. The increasing rate of substrate $\mathrm{pH}$ was observed to be greater than the decreasing rate.

The ash content, an important indicative parameter for decomposition and mineralization of the substrate $[5,19,22,37]$ was observed to be increasing with time of vermicomposting in all the experimental runs. The increase in ash content was slower up to 9 days of vermicomposting in all the above stated runs including the controls. When compared to other runs, the experimental runs having 4.3 and 4.8 initial substrate $\mathrm{pH}$ showed slower rate of increase even after 9 days. In remaining runs, a faster rate of increase in ash content was observed after 9 days of vermicomposting. However, a faster rate of increase was observed after 18 days of vermicomposting in the runs having 4.3 and 4.8 initial substrate $\mathrm{pH}$. The ash content (the measure of degradation) beyond 35 days tended to be stabilized in the experimental runs having 5.2, 5.9, 6.5, and 6.9 initial substrate $\mathrm{pH}$. The overall rate of increase in the ash content was observed to be higher as compared to their respective controls. 
Table 2. Variation of ash content (\% dry basis) with different initial substrate $p H$ during vermicomposting

\begin{tabular}{c|cccccc|ccccccc}
\hline \multirow{2}{*}{ days } & \multicolumn{10}{c}{ initial $\mathbf{~ H ~}$} \\
& $\mathbf{4 . 3}$ & $\mathbf{4 . 8}$ & $\mathbf{5 . 2}$ & $\mathbf{5 . 9}$ & $\mathbf{6 . 5}$ & $\mathbf{6 . 9}$ & $\mathbf{4 . 3}$ & $\mathbf{4 . 8}$ & $\mathbf{5 . 2}$ & $\mathbf{5 . 9}$ & $\mathbf{6 . 5}$ & $\mathbf{6 . 9}$ \\
\cline { 2 - 13 } & \multicolumn{4}{c}{ Ash content with earthworms } & & \multicolumn{1}{c}{ Ash content without earthworms } \\
\hline 0 & 12.8 & 12.7 & 12.5 & 12.4 & 12.3 & 12.2 & 12.8 & 12.7 & 12.5 & 12.4 & 12.3 & 12.2 \\
3 & 13.1 & 13 & 12.9 & 12.9 & 12.8 & 12.9 & 13.1 & 13 & 12.9 & 12.8 & 12.8 & 12.9 \\
6 & 13.8 & 13.8 & 14.1 & 14.3 & 14.3 & 14.4 & 13.8 & 13.8 & 14.1 & 14.1 & 14.2 & 14.2 \\
9 & 14.9 & 15.2 & 15.5 & 15.7 & 15.8 & 15.9 & 14.8 & 14.9 & 15 & 15.1 & 15.1 & 15.2 \\
12 & 16.2 & 16.5 & 17.2 & 17.3 & 17.8 & 18 & 16.1 & 16.3 & 16.6 & 16.8 & 17 & 17.2 \\
15 & 18.3 & 18.7 & 20 & 20.1 & 20.9 & 21.6 & 18.1 & 18.6 & 19.5 & 19.7 & 19.7 & 19.9 \\
18 & 20.5 & 20.9 & 22.4 & 23.6 & 24.5 & 25.3 & 20.2 & 20.6 & 22 & 22.1 & 22.3 & 22.6 \\
21 & 22.7 & 23.1 & 24.2 & 26.7 & 27.6 & 28.2 & 22.4 & 22.8 & 24.1 & 24.2 & 24.5 & 24.8 \\
24 & 25.3 & 25.8 & 26.4 & 30.2 & 31.4 & 32.6 & 25 & 25.5 & 26.8 & 27 & 27.3 & 27.9 \\
27 & 28.2 & 28.9 & 29.8 & 33.6 & 34.9 & 35.8 & 27.8 & 28.3 & 29.9 & 30.1 & 30.2 & 30.6 \\
30 & 31.8 & 32.1 & 33.9 & 34.9 & 36.1 & 38.6 & 31.1 & 31.7 & 34.1 & 34.2 & 34.3 & 34.7 \\
35 & 35.6 & 36.2 & 38.5 & 38.5 & 39.9 & 41.2 & 34.8 & 35.3 & 38.4 & 38.5 & 38.6 & 39.2 \\
40 & 41.1 & 41.3 & 43.6 & 43.6 & 43.8 & 43.9 & 38.6 & 39.2 & 41.7 & 41.7 & 41.9 & 42.1 \\
45 & 46.7 & 47.1 & 47.2 & 47.2 & 47.3 & 47.3 & 43.3 & 43.6 & 43.9 & 43.9 & 44.1 & 44.3 \\
\hline
\end{tabular}

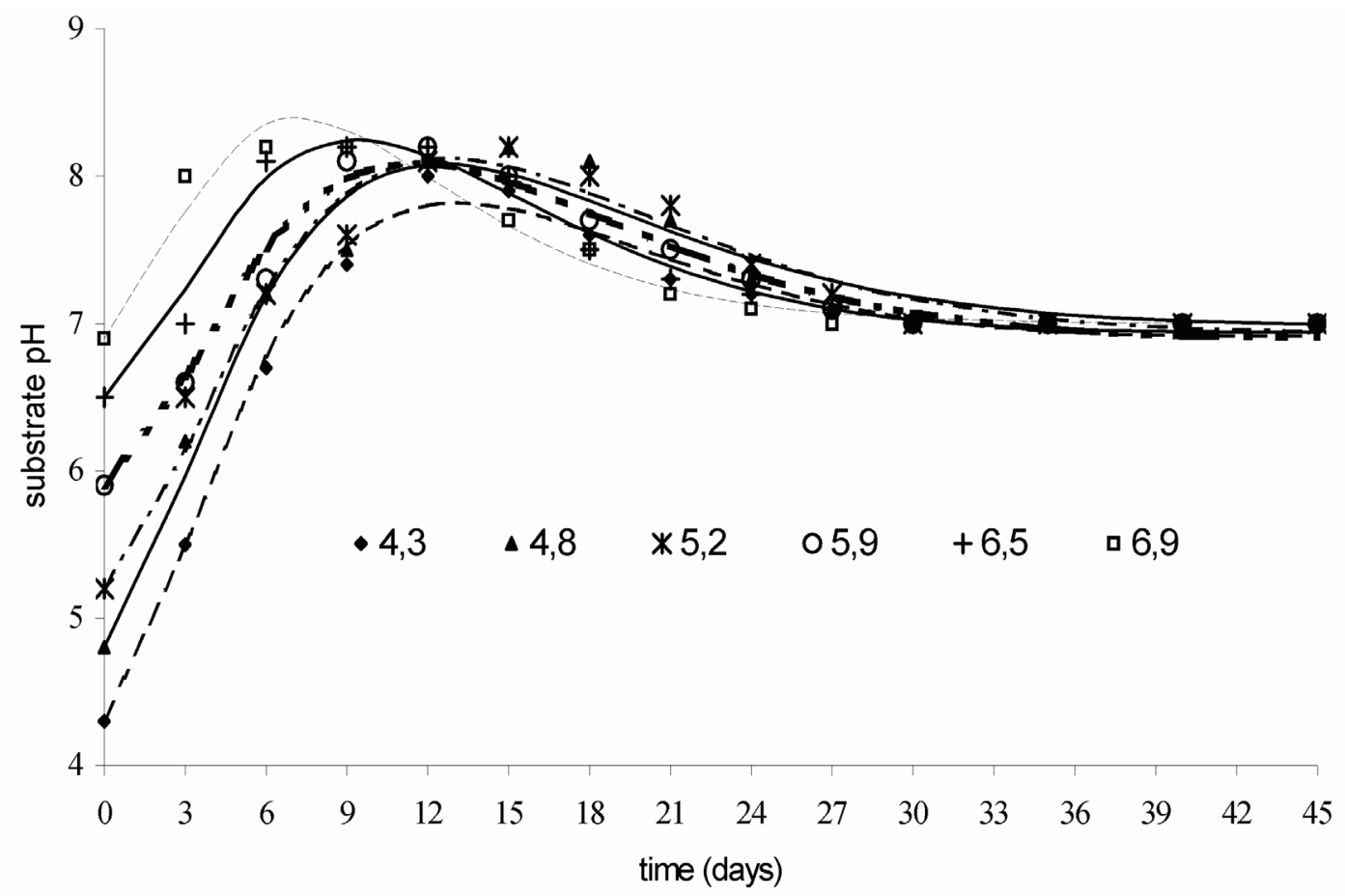

Figure 1. Variation of substrate $\mathrm{pH}$ with different initial substrate $\mathrm{pH}$

The ash content, an important indicative parameter for decomposition and mineralization of the substrate [5, 19, 22, 37] was observed to be increasing with time of vermicomposting in all the experimental runs. The increase in ash content was slower up to 9 days of vermicomposting in all the above stated runs including the controls. When compared to other runs, the experimental runs having 4.3 and 4.8 initial substrate $\mathrm{pH}$ showed slower rate of increase even after 9 days. In remaining runs, a faster rate of 
increase in ash content was observed after 9 days of vermicomposting. However, a faster rate of increase was observed after 18 days of vermicomposting in the runs having 4.3 and 4.8 initial substrate $\mathrm{pH}$. The ash content (the measure of degradation) beyond 35 days tended to be stabilized in the experimental runs having 5.2, 5.9, 6.5, and 6.9 initial substrate $\mathrm{pH}$. The overall rate of increase in the ash content was observed to be higher as compared to their respective controls.

\section{Analysis}

The variations of substrate $\mathrm{pH}(\phi)$ corresponding to each value of initial substrate $\mathrm{pH}$ $\left(\phi_{i}\right)$ up to 45 days of vermicomposting (excluding controls) are plotted with respect to time of vermicomposting (T) in days (Fig. 1 ).

It may be noted that the $\phi$ values of controls were left out as they did not reflect action of earthworms. The data sets corresponding to experimental values of $\phi$ were used for modeling purposes, and to establish a possible correlation between $\phi$ and T. The lines of best fits (computed on least square error basis) with respect to each $\phi_{\mathrm{i}}$ were obtained using iterative programs are also shown in the above figure (Fig. 1).

All the stated curves follow exponential relationships as shown in Eq. 1 manifesting high $\mathrm{R}^{2}$ values.

$$
\phi=A T^{2} \mathrm{e}^{-r T}+\left(\phi_{i}-\phi_{f}\right) \mathrm{e}^{-q T}+\phi_{f}
$$

In Eq. $1, A, r$ and $q$ are model parameters whereas $\phi_{i}, \phi_{f}$ and $T$ represent initial substrate $\mathrm{pH}$, final substrate $\mathrm{pH}$ and time of vermicomposting in days respectively. The values of the model parameters $A, r$, and $q$ for all the experimental runs are presented in Table 3.

Table 3: Model parameters $A, r$ and $q$ variation with different initial substrate $p H\left(\phi_{i}\right)$

\begin{tabular}{c|cccc}
\hline \multirow{2}{*}{ initial substrate pH $\left(\phi_{i}\right)$} & \multicolumn{4}{|c}{ model parameter } \\
& $A$ & $r$ & $q$ & $R^{2}$ \\
\hline 4.3 & 0.13885 & 0.19113 & 0.06635 & 0.9902 \\
4.8 & 0.1339 & 0.19455 & 0.0852 & 0.9611 \\
5.2 & 0.1232 & 0.18242 & 0.05993 & 0.9622 \\
5.9 & 0.11703 & 0.19043 & 0.04605 & 0.9787 \\
6.5 & 0.14586 & 0.2237 & 0.04379 & 0.971 \\
6.9 & 0.21176 & 0.2848 & 0.21 & 0.9636 \\
\hline
\end{tabular}

Further, weighted mean of the model parameter q was calculated by the formula $q_{\text {weighted }}=\sum\left[\left(\phi_{f}-\phi_{i}\right) \times q\right] / \sum\left(\phi_{f}-\phi_{i}\right)$ which comes out to be 0.06762 . The values of model parameters $A$ and $r$, when regressed (using least square regression technique) with respect to the initial substrate $\mathrm{pH}\left(\phi_{i}\right)$ followed parabolic trends as shown in Figs. 2 and 3.

The respective expressions are shown in Eqs. 2 and 3:

$$
\begin{aligned}
& A=0.0343 \phi_{i}{ }^{2}-0.3643 \phi_{i}+1.0819 \\
& r=0.0312 \phi_{i}{ }^{2}-0.3212 \phi_{i}+1.0035
\end{aligned}
$$

Substituting the value of model parameter $q$ in $E q$. 1, following expression is obtained:

$$
\phi=A T^{2} \mathrm{e}^{-r T}+\left(\phi_{i}-\phi_{f}\right) \mathrm{e}^{-0.06762 T}+\phi_{f}
$$




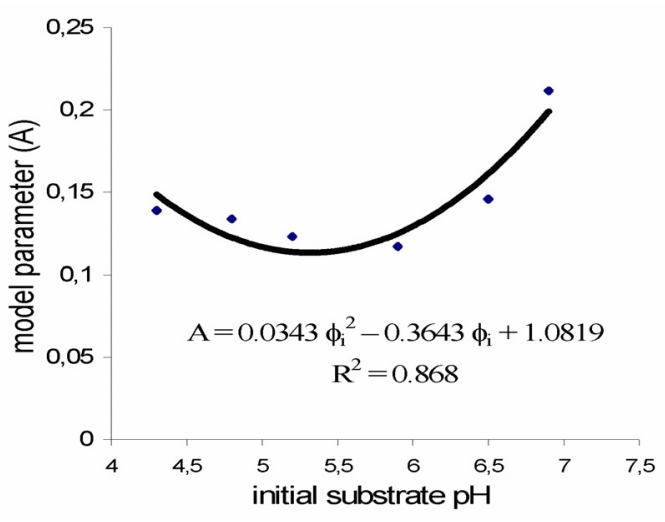

2

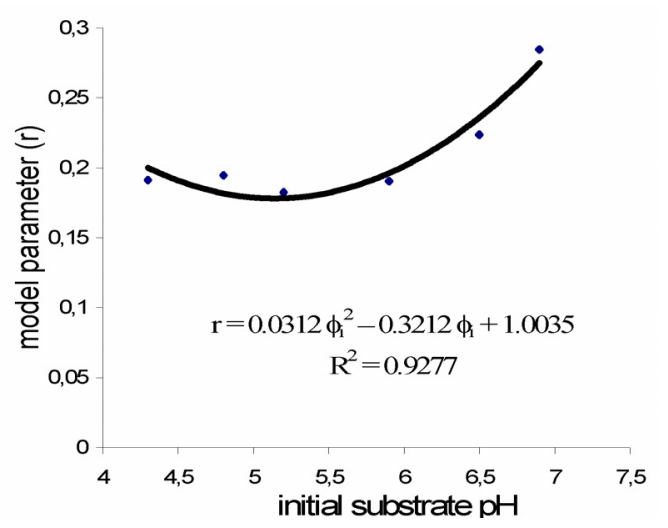

3

Figures 2 and 3. Variation of model parameters (A) with initial substrate $p H$. 2: parameter A; 3: parameter $r$

Eqs. 2-4 together gives a generalized predictive model for predicting the substrate $\mathrm{pH}(\phi)$ at various stages of vermicomposting. The proposed models $(E q .4$ together with Eqs. 2 and 3) for predicting $\phi$ at the various $\phi_{i}$ values can be used in predicting the substrate $\mathrm{pH}(\phi)$.

On the basis of the above stated generalized and predictive model, the $\phi$ values were computed for comparison with the observed experimental values. $\phi$ (experimental) and $\phi$ (computed) values were plotted as a scatter diagram (Fig. 4) and a correlation $\phi_{\text {computed }}=1.0071 \phi_{\text {experimental }}-0.0125$ was obtained by linear fitting using the least square regression technique. The maximum and average absolute errors of the computed values of $\phi$ are $5.6341 \%$ and $1.3877 \%$ respectively. The negligible error values manifest the robustness of the proposed models.

The variations of ash content $(\alpha)$ with each value of the initial substrate $\mathrm{pH}\left(\phi_{\mathrm{i}}\right)$ are plotted as a function of time (T) representing the duration of vermicomposting (Fig. 5). As stated earlier, the control data was excluded as it did not reflect effect of the earthworms.

The nature of each plot for the variation of the ash content $(\alpha)$ is similar to phase Bode plot of a single zero system [23]. Phase Bode plot of a single zero system plots $\tan ^{-1}\left(\omega / \omega_{c}\right)$ against $\log \omega$ (where $\omega=$ angular frequency and $\omega_{c}=$ corner angular frequency). The plot starts at 0 with $\omega=0$, i.e. $\log \omega=-\infty$ and monotonically increases to a final value $\pi / 2$ with $\omega=\infty$, i.e. $\log \omega=\infty$. At $\omega=\omega_{c}$, the $\tan ^{-1}\left(\omega / \omega_{c}\right)$ value becomes $\pi / 4$ and the slope is maximum. The slope decreases on either side of this point. The nature of the slope and monotone increase is similar to the observed experimented data of $\alpha$. The experimental $\alpha$ is expected to reach a final constant value although it was increasing (slowly) till the last day of observation. Therefore, this curve form was tested for deriving the trend lines. The $\mathrm{X}$ axis in Bode plot is logarithmic $(\log \omega)$ but in the presented case it is linear $(T)$. So, instead of $\tan ^{-1}\left(\omega / \omega_{c}\right)$, antilog to an arbitrary base $a$ was taken to obtain $\tan ^{-1}\left(a^{T} / a^{T c}\right)=$ $\tan ^{-1} a^{(T-T c)}$ which will attain a value of $\pi / 4$ at $T=T c$. The initial ash content at $a^{T}=0$ (for $T=-\infty)$ is obviously not zero in the present case and therefore a finite presumed value of ash content $\left(\alpha_{i}\right)$ was taken for it. 


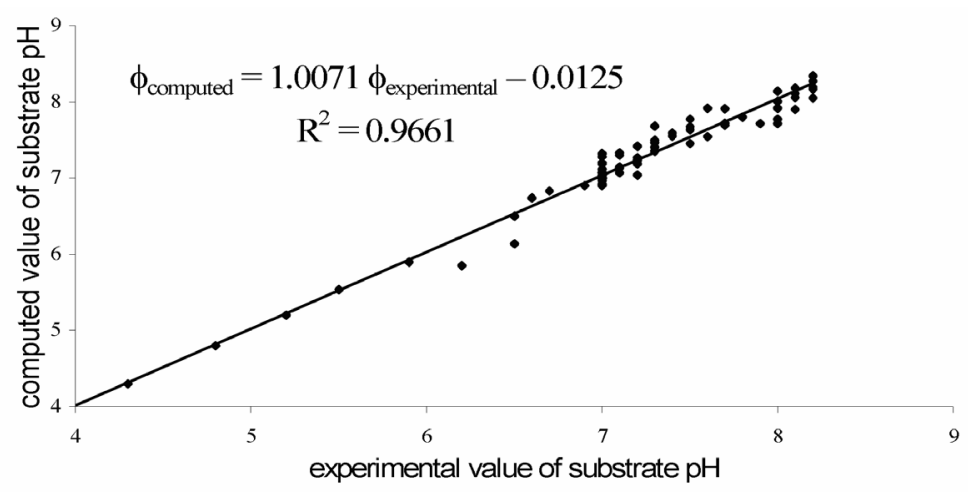

Figure 4. Comparison of computed and experimental value of substrate $\mathrm{pH}$

Similarly, increase in ash content from $a^{T}=0$ to $\infty$ (for $T=-\infty$ to $+\infty$ ) is also not $\pi / 2$. Therefore, the increase in ash content for the entire period of $T=-\infty$ to $+\infty$ was assumed to be $\alpha_{d}$. A generalized trend line relationship was obtained as shown in Eq. 5:

$$
\alpha=\alpha_{i}+\left(2 \alpha_{d} / \pi\right) \tan ^{-1} a^{(T-T c)}
$$

In Eq. 5, $\alpha=$ ash content at anytime $T ; \alpha_{i}=$ presumed ash content at time $T=-\infty$ (this can not however, be verified physically); $\alpha_{d}=$ increase in ash content for the entire period of $T=-\infty$ to $+\infty$; and $T c=$ time at which half increase in ash content is achieved.

The trend lines (variation plots) for ash content with different initial substrate $\mathrm{pH}$ (excluding control) were computed on least square error basis from $E q .5$ using an iterative program are also presented (Fig. 5). Resulting values of model parameters $\left(\alpha_{i}\right.$, $\alpha_{d}, a$, and $T c$ ) and $R^{2}$ for the various initial substrate $\mathrm{pH}$ are presented in Table 4. The $R^{2}$ values were obtained by linearly correlating the computed and experimental $\alpha$ values for each initial substrate $\mathrm{pH}$.

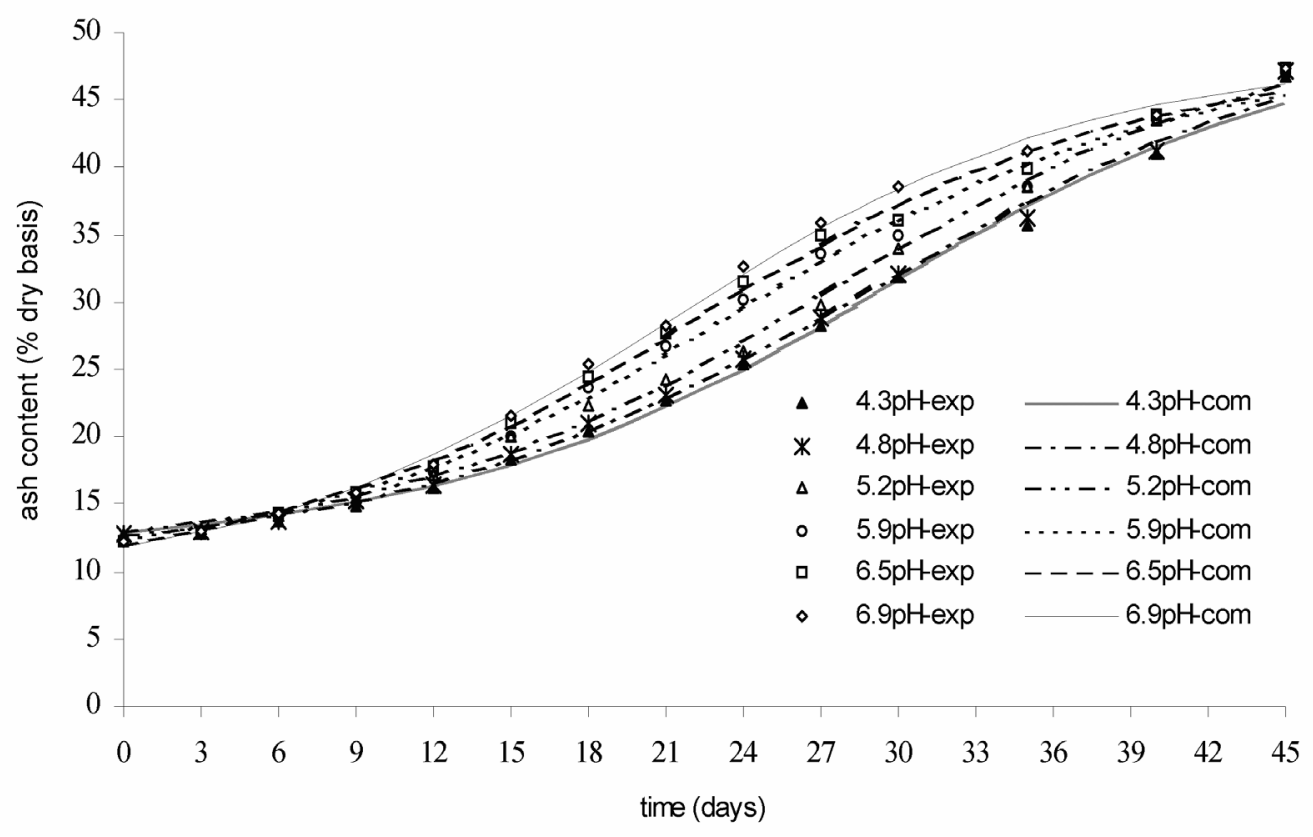

Figure 5. Variation of ash content with different initial substrate $\mathrm{pH}$ 
The model parameters $\alpha_{i}$ and Tc as presented in Table 4 were expected to be functions of initial substrate $\mathrm{pH}\left(\phi_{i}\right)$. Therefore, $\alpha_{i}$ and $T c$ were fitted with initial substrate $\mathrm{pH}$ using least square regression technique. The equations obtained thereby are as follows:

$$
\begin{aligned}
& \alpha_{i}=-1.1049 \phi_{i}+16.051 \\
& T c=-3.63 \phi_{i}+45.929
\end{aligned}
$$

The corresponding $R^{2}$ values are 0.9177 and 0.9618 respectively. The resulting trend lines along with $\alpha_{i}$ and Tc values given in Table 4 are presented in following figures (Figs. 6 and 7).

\begin{tabular}{|c|c|c|c|c|c|}
\hline \multirow{2}{*}{ initial pH $\left(\phi_{i}\right)$} & \multicolumn{4}{|c|}{ model parameter } & \multirow{2}{*}{$R^{2}$} \\
\hline & $\alpha_{i}$ & $\alpha_{d}$ & $a$ & $T c$ & \\
\hline 4.3 & 11.26003 & 39.69997 & 1.09445 & 29.51283 & 0.9954 \\
\hline 4.8 & 10.31496 & 42.49997 & 1.08531 & 29.49997 & 0.9964 \\
\hline 5.2 & 10.90003 & 40.49997 & 1.09446 & 27.57043 & 0.9964 \\
\hline 5.9 & 9.5675 & 39.29997 & 1.096072 & 23.67348 & 0.9944 \\
\hline 6.5 & 8.78478 & 40.09997 & 1.09617 & 22.26143 & 0.9963 \\
\hline 6.9 & 8.35441 & 40.5025 & 1.1 & 21.08998 & 0.998 \\
\hline Mean & 一 & 40.43372 & 1.09441 & - & - \\
\hline
\end{tabular}

Table 4: Model parameters $\alpha_{i}, \alpha_{d}$, a and Tc variation with different initial $p H\left(\phi_{i}\right)$

The corresponding $R^{2}$ values are 0.9177 and 0.9618 respectively. The resulting trend lines along with $\alpha_{i}$ and Tc values given in Table 4 are presented in Figs. 6 and 7.

As model parameters $\alpha_{d}$ and $a$ did not show significant correlation with initial substrate $\mathrm{pH}\left(\phi_{\mathrm{i}}\right)$, mean values for both these parameters were considered for evolving a generalized predictive model. Substituting mean values of $\alpha_{d}$ and $a$ in Eq. 5, an expression for predicting $\alpha$ is obtained as follows:

$$
\alpha=\alpha_{i}+25.74345 \tan ^{-1} 1.09441^{(T-T c)}
$$

Eqs. 5-8 together gives a generalized model for $\alpha$ as a function of $\phi_{i}$ and $T$. It is important to mention that sub periodic (day and night) variations of ash content were not studied although earthworms being nocturnal $[12,20]$ become more active in night.

The validity of the proposed model was verified by computing values of $\alpha$ accordingly and linearly correlating them to the experimental results as shown in the scatter diagram (Fig. 8). The resulting equation gives $\alpha_{\text {computed }}=0.9889 \alpha_{\text {experimental }}+$ 0.2713 with $R^{2}=0.9953$.

The maximum and average absolute errors of computed values of $\alpha$ with respect to experimental values are $7.14 \%$ and $2.29 \%$ respectively, justifying robustness of the predictive model. The decreasing nature of half processing time (Tc) as shown in Fig. 7 indicates lower processing time for substrate having initial $\mathrm{pH}$ values nearer to neutral.

\section{Discussion}

The observations carried out for 45 days of vermicomposting revealed that earthworms play a significant role in the processing of substrates having different initial $\mathrm{pH}$, as almost complete decomposition was observed in the experiments with earthworms, while decomposition process was continued in the respective controls. 
The initial increase in the substrate $\mathrm{pH}$ can be attributed to the fact that initially microbes participate in the degradation representing aerobic metabolism. As a result, basic hydroxides are formed in the presence of sufficient moisture which increases the substrate $\mathrm{pH}$ in the initial phase of decomposition [32]. Subsequently, the conversion of complex compounds into simpler forms during the log and stabilization phases of microbial action causes formation of weak acids, which become predominant in comparison to formation of basic compounds and/or hydroxides. The net effect of more acid and lesser basic formations was manifested as a decrease in the substrate $\mathrm{pH}$ at a slower rate up to 30 days after which the substrate $\mathrm{pH}$ was almost constant as the substrate tended to be stabilized. Initial increase in first week and subsequent decrease till fourth week without earthworm and sixth week with earthworm was also observed during the study of changes in biochemical properties of cow manure by earthworms (Eisenia andrei Bouche) [5]. The substrate (coffee pulp) having an initial pH 4.1 was analyzed during vermicomposting using E. fetida, P. excavatus and E. andrei and reported that substrate $\mathrm{pH}$ became neutral $(6.5-7.4)$ on $15^{\text {th }}$ day and then it turned into basic (8-9) for 15 weeks. At the end of the decomposition process, it was found that the substrate in all the treatments was neutral while slightly acidic in control [33]. In contrast to this, very slight changes in $\mathrm{pH}$ values of substrate (cow manure) with and without earthworms (E. andrei) were reported [5]. The substrate $\mathrm{pH}$ values with earthworms decreased slightly after 4 weeks, whereas without earthworms, the $\mathrm{pH}$ value of the manure increased and moved towards neutrality.

Finally, a constant pattern with neutral values of $\mathrm{pH}$ in vermicomposting and 6.8-6.9 in control were observed. The slightly higher and neutral value of substrate $\mathrm{pH}$ with earthworms can be ascribed to conversion of substrate into earthworm castings which is reported to be neutral $[7,12,24,40]$.

The ash content increased till last day of observation in all the experiments with almost similar trend. The slower increase in ash content up to 9 days of vermicomposting in all the above stated runs is probably due to the acclimatizing effect and initial weathering (softening) of the substrate. This can also be ascribed to the initial phase of decomposition, which takes place due to action of micro flora, fungi and actinomycetes in the presence of simple forms of available nutrients in the substrate $[12,37]$. The earthworms start consuming the substrate after initial decomposition (weathering), when substrate becomes palatable to them [12]. Further, fastest rate of increase in ash content was observed between $15^{\text {th }}$ to $30^{\text {th }}$ days of vermicomposting, which can be attributed to log phase of microbial activity [25], and increased palatability of substrate to earthworms due to its softening after initial decomposition. After lag phase of microbial growth, complex compounds like carbohydrates, fats, proteins, vitamins and minerals present in the substrate are converted into simpler forms such as sugars, starch, glycerol, fatty acids, amino acids, calcium, iron and potassium. These simpler forms of nutrients and compounds enhance the microbial action [37]. The faster rate of increase in ash content can also be attributed to the conversion of substrate into finer particles due to breakdown and fragmentation of substrate in the intestine as well as grinding action in the gut of earthworms [8, 10]. The consumed substrate is excreted by earthworms as vermicastings having very fine particles due to which volume of substrate ultimately decreases and have a higher surface to volume ratio [16]. The higher surface to volume ratio also enhances the microbial activity [12]. Faster rate of increase in ash content indicated the higher rate of volatilization, which is a good measure of degradation of the organic waste. 


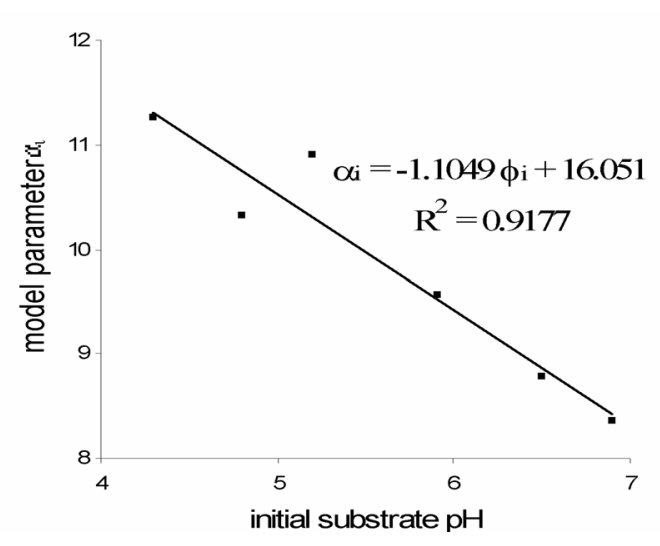

6

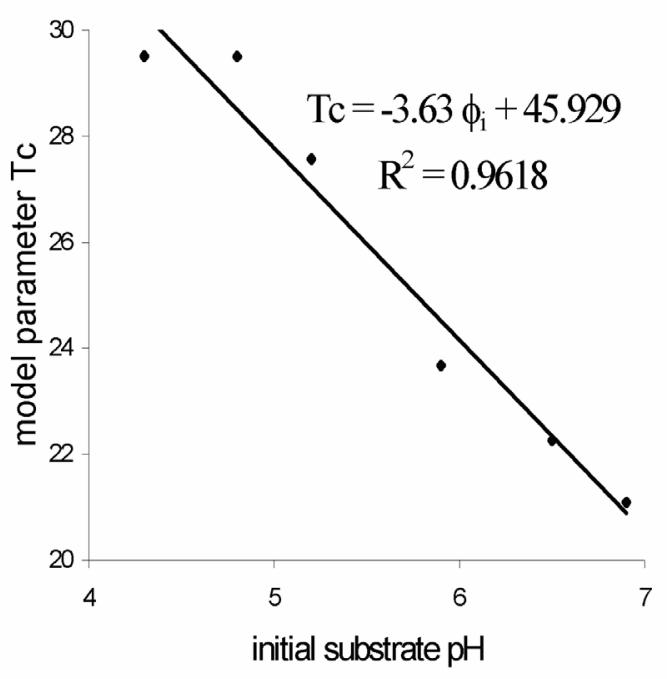

7

Figures 6 and 7. Variation of model parameters $a_{i}$ and Tc with initial substrate $p H$. 6: parameter $a_{i}$; 7: parameter Tc

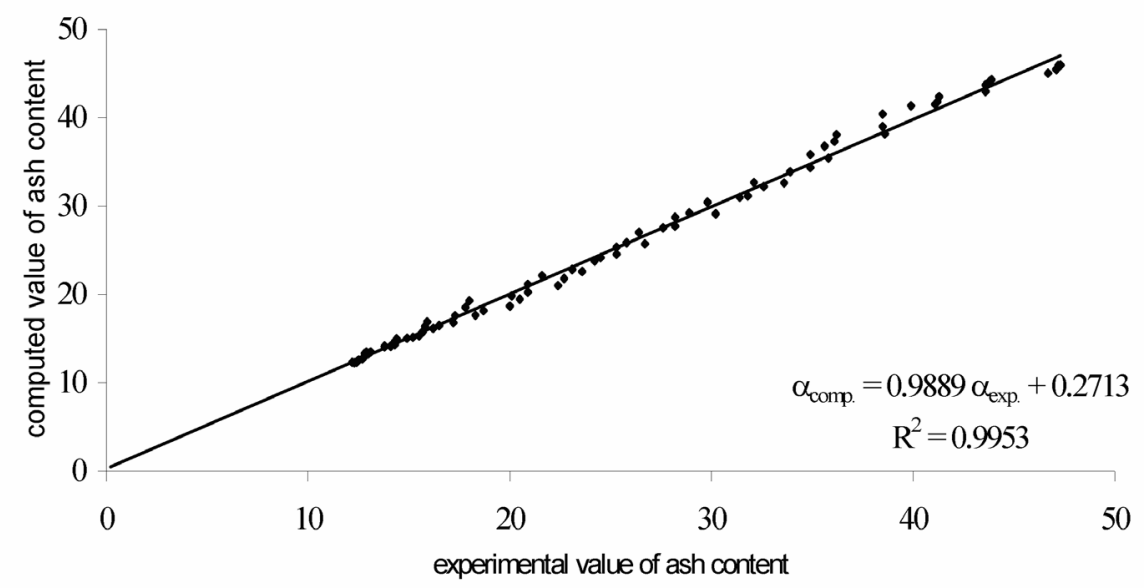

Figure 8. Comparison of computed and experimental value of ash content

The experimental runs having 4.3 and 4.8 initial substrate $\mathrm{pH}$ showed more slower decomposition initially (as depicted from the values of ash content at different periods). The lesser increase in ash content and decomposition can be attributed to lesser assimilation by microbial population and lesser palatability of the substrate to earthworms due to acidic nature of the substrate in the initial phase of vermicomposting.

The substrates having 5.2, 5.9, 6.5 and 6.9 initial substrate $\mathrm{pH}$ showed faster increase in ash content and depicted the higher rate of volatilization/degradation. However, substrate having 6.9 initial substrate $\mathrm{pH}$ showed fastest rate of volatilization and simultaneous four fold (approximately) increase in ash content from $12.2 \%$ to $47.3 \%$ was observed. Six folds increase [19] three and half folds increase [37] two folds increase [22] and two folds increase [5] have already been reported during vermicomposting. It is thus depicted that near neutral initial substrate $\mathrm{pH}$ is optimum for quicker stabilization of the organic solid wastes using $P$. excavatus. Similar recommendations have been given by different workers using different epigeic earthworm species in waste management [3, 7, 11, 12, 20, 37]. Further, almost complete 
degradation was observed in 40-45 days of vermicomposting resulting in $46.7 \%$ to $47.3 \%$ ash content in all above stated runs with earthworms. The study reveals that the ash content is significantly influenced by the initial substrate $\mathrm{pH}$ and varies with time in the initial phase of vermicomposting. As stated earlier, the increase in ash content was observed till last day of observation. Practically it is obvious that ash content can not reach an infinite value, and will settle down to a finite upper bound. Since, the objective of the investigation was to predict minimum processing time; the observation period was hence limited till the complete decomposition of substrate was achieved.

The results of substrate $\mathrm{pH}$ and ash content variation depicts that initial substrate $\mathrm{pH}$ have lesser significant effect on the vermicomposting and Perionyx excavatus can perform excellently in a wide range of $\mathrm{pH}$ (4.3 to 8.2). However, stabilization of organic wastes having near neutral $\mathrm{pH}$ initially is seems to be optimum for vermicomposting as depicted from increase in ash content.

The proposed model for predicting $\phi$ as a function of initial substrate $\mathrm{pH}$ and time of vermicomposting gives faster rising pattern initially due to double interaction between first and second terms of Eq. 4 as both these exponential terms gives rising pattern. Further, it attains a slower decreasing trend as first term gives faster falling pattern whereas second term gives rising pattern which compensates the faster falling trend. The $\phi$ values becomes near constant after 30 days of vermicomposting due to the reason that when $T \rightarrow \infty$, the first and second terms become zero and as a result only $\phi_{f}$ reflects its magnitude.

The predictive model expressing the ash content as a function of the initial substrate $\mathrm{pH}$ and the time of vermicomposting can be used for determining the ash content to achieve the desired level of decomposition (approximately $45 \%$ ash content on dry basis showed complete decomposition) at specific initial substrate $\mathrm{pH}$.

The lower values of absolute maximum and average errors of the ash content and substrate $\mathrm{pH}$ computed from generalized predictive models fully justifies their robustness.

\section{REFERENCES}

[1] Albanell, E., Plaixats, J. \& Cabrero, T. (1988): Chemical changes during vermicomposting (E. fetida) of sheep manure mixed with cotton industries waste. Biology and Fertility of Soils 6(3): 266-269.

[2] Allee, W.C., Torvik, M.M., Lahr, J.P. \& Hollister, P.L. (1930): Influence of soil reaction on earthworms. - Physiol. Zoology 3(2): 164-200.

[3] Aranda, E., Barois, I., Arellano, P., Irisson, S., Salazar, T., Rodriguez, J., \& Patron, J.C. (1999): Vermicomposting in the Tropics. - In: Lavelle, P., Brussaard, L. \& Hendrix, P. (eds.): Earthworm management in tropical agroecosystems. CAB International, pp. 253-287.

[4] Arrhenius, O. (1921): Influence of soil reaction on earthworms. - Ecology 2: 255-257.

[5] Atiyeh, R.M., Dominguez, J., Subler, S. \& Edwards, C.A. (2000): Changes in biochemical properties of cow manure during processing by earthworms (Eisenia andrei Bouche) and the effects on seedling growth. - Pedobiologia 44: 709-724.

[6] Bansal, S. \& Kapoor, K.K. (2000): Vermicomposting of crop residues and cattle dung with Eisenia foetida. - Bioresource Technology 73: 95-98.

[7] Bhawalkar, U.S. (1995): Vermiculture bioconversion of organic residues. - Ph.D. Thesis, I.I.T. Mumbai, India

[8] Camp, Dresser, McKee Inc. (1980): Compendium on solid waste management by vermicomposting. Cincinnati, OH, Municipal Environmental Research Lab, EPA. 
[9] Chan, P.L.S. \& Griffiths, D.A. (1988): The vermicomposting of pre treated pig manures. - Biological Wastes 24(1): 57-69.

[10] Edwards, C.A. \& Lofty, J.R. (1977): Biology of earthworms. - Chapman and Hall, London.

[11] Edwards, C.A. (1995): Earthworm. McGraw-Hill Encyclopedia, pp. 81-83.

[12] Edwards, C.A. \& Bohlen, P.J. (1996): Biology and ecology of earthworms (3rd ed.). Chapman and Hall, London.

[13] Edwards, C.A., Dominguez, J. \& Neuhauser, E.F. (1998): Growth and reproduction of Perionyx excavatus (Perr.) (Megascolecidae) as factors in organic waste management. Biology and Fertility of Soils 27: 155-161.

[14] Gates, G.F. (1972). Burmese earthworms. An introduction to the systematics and biology of megadrile oligochaetes with especial reference to South East Asia. - Trans Am. Philo. Soc. 62(7): 1-326.

[15] Guild, W.J.Mc.L. (1951): Earthworms in agricultures. - Scottish Agriculture 30(4): 220-223.

[16] Haimi, J. \& Huhta, V. (1987): Comparison of composts produced from identical wastes by 'Vermistabilization' and conventional composting. - Pedobiologia 30: 137-144.

[17] Hallatt, L., Reinecke, A.J. \& Viljoen, S.A. (1990): The life cycle of the oriental compost worm Perionyx excavatus (Oligochaeta). - South African Journal of Zoology 25: 41-45.

[18] Hallatt, L. (1992): Moisture requirements in life cycle of Perionyx excavatus. - Soil Biology and Biochemistry 24(12): 1333-1340.

[19] Hartenstein, R. \& Hartenstein, F. (1981): Physicochemical changes in activated sludge by the earthworm Eisenia foetida. - Journal of Environmental Quality 10: 377-382.

[20] Ismail, S.A. (1997): Vermicology - the biology of earthworms. Orient Longman Limited, Hyderabad (A.P.), India.

[21] Kale, R.D., Bano, K. \& Krishnamoorthy, R.W. (1982): Potential of Perionyx excavatus for utilization of organic wastes. - Pedobiologia 23: 419-426.

[22] Kavian, M.F. \& Ghatnekar, S.D. (1991): Biomanagement of dairy effluents using culture of red earthworms (L. rubellus). - Indian Journal of Environmental Protection 11(9): 680-682.

[23] Kuo, B.C. (2001): Automatic control systems. Prentice Hall of India Private Limited, New Delhi, India.

[24] Lunt, L.A. \& Jacobson, G.M. (1944): The chemical composition of earthworm casts. Soil Science 58: 367.

[25] Metcalf \& Eddy (2003): Wastewater engineering treatment and reuse. Tata McGraw-Hill Edition, New Delhi.

[26] Murphy, D.J. (1993): Earthworms in Australia. Hyland House Publishing Pvt Ltd, Victoria.

[27] Olson, H.W. (1928): The earthworms of Ohio. - Ohio Biological Survey Bulletin 17: 47-90.

[28] Petrov, B.C. (1946): The active reaction of soil $(\mathrm{pH})$ as a factor in the distribution of earthworms. - Zoological Journal 25(1): 107-110.

[29] Reinecke, A.J. \& Hallatt, L. (1989): Growth and cocoon production Perionyx excavatus (Oligochaeta). - Biology and Fertility of Soils 8: 303-306.

[30] Reinecke, A.J., Viljoen, S.A. \& Saayman, R.J. (1992): The suitability of Eudrilus eugeniae, Perionyx excavatus and Eisenia fetida (Oligochaeta) for vermicomposting in Southern Africa in terms of their temperature requirements. - Soil Biology and Biochemistry 24: 1295-1307.

[31] Richardson, H.C. (1938): The nitrogen cycle in grassland soils. - Journal of agricultural science 28: 73-121.

[32] Rynk, R.M., Kamp, V.D., Willson, G.G., Singley, M.E., Richard, T.L., Kolega, J.J., Gouin, F.R., Laliberty, L. Jr., Kay, D., Murphy, D. H., Hoitink, A.J. \& Brinton, W.F. (1992): On-farm composting handbook. - In: Rynk, R. (ed.): NRAES-54, Natural resource, agriculture and engineering service. $186 \mathrm{pp}$. 
[33] Salazar, T.C., Aranda, E. \& Barois, I. (1995): Estudio comparative del lombricompostaje de la pulpa de café por Eisenia andrei, Eisenia fetida y Perionyx excavatus en condiciones de campo. - In: Barois, I. \& Aranda, E. (eds.): Utilizacion de Lombrices en la Transformacion de la Pulpa de Café en Abono Organico. CONACyT (clave: 045N9108). Final report, pp. 28-41.

[34] Salisbury, E.J. (1925): The influence of earthworms on soil reaction and the stratification of undisturbed soils. - Journal Linn. Soc. (Bot) 46: 415-425.

[35] Santamaria-Romero, S. \& Ferrera-Cerrato, R. (2002): Population dynamics of Eisenia andrei (Bouche 1972) in different organic wastes. - Terra 20: 303-310.

[36] Satchell, J.E. (1955): Some aspects of earthworm ecology. - In: Keven, D.K.Mc E. (ed.): Soil zoology. Butterworths, London.

[37] Singh, N.B., Khare, A.K., Bhargava, D.S. \& Agrawal, S. (2003): Vermicomposting of tomato skin and seed waste. - Journal of the Institution of Engineers (India) (Environmental Engineering Division) 84: 30-34.

[38] Stephenson, J. (1930): The Oligochaeta. Oxford University Press, Oxford.

[39] Tripathi, G. \& Bhardwaj, P. (2004): Comparative studies on biomass production, life cycles and composting efficiency of Eisenia fetida (Savigny) and Lampito mauritii (Kinberg). - Bioresource Technology 92(3): 275-283.

[40] Wallwork, J.A. (1983): Earthworm biology. Edward Arnold (Publishers) Ltd, London. 